\title{
Penggunaan Media Flash Player bagi Meningkatkan Keterampilan Berpidato Murid Kelas X SMA Negeri 1 Sinjai Tengah Kabupaten Sinjai
}

\section{Muhammad Dahlan}

\section{PendidikanBahasa dan Sastra Indonesia Fakultas Keguruan dan Ilmu Pendidikan Universitas Muhammadiyah Makassar}

muhdahlan@unismuh.ac.id

\begin{abstract}
Abstrak
Penelitian ini ialah tindbagi kelas (Action Research Classroom) yang berguna bagi mendeskripsikan penggunaan media flash player dalam mengembangkan keterampilan berpidato murid kelas X SMA Negeri 1 Sinjai Tengah Kabupaten Sinjai. Pokok penelitian ini ialah murid kelas X dengan jumlah murid 33 murid yang terdiri dari 15 murid lakilaki dan 18 murid perempuan. Penelitian ini memakai media flash layer dalam meningkatkan keterampilan berpidato murid yang memakai dua siklus yakni siklus I serta siklus II. Setiap siklus dilaksanbagi 4 kali pertemuan. Teknik pengumpulan data yang digunbagi dalam penelitian ini ialah dengan menyerahkan tes hasil belajar berpidato pada murid di setiap akhir siklus, data tentang proses belajar mengajar diambil melalui lembar observasi. Data yang telah diperoleh dianalisis menggunbagi analisis statistik deskripti kuantitatif dan deskriptif kualitatif. Data hasil analisis kuantitatif memperlihatkan adanya peningkatan hasil belajar murid, hal ini ditandai dengan meningkatnya skor rata-rata hasil belajar murid pada siklus I yakni 59,66 dengan standar deviasi 11,32 dan pada siklus II skor rata-rata meningkat menjadi 72,24 dengan standar deviasi 12,20 dengan skor maksimal 100. Sedangkan secara kualitatif terjadi peningkatan aktivitas belajar murid yakni ditandai dengan meningkatnya kehadiran murid, keaktifan murid dalam proses belajar mengajar, semakin banyak murid yang memperhatikan penjelasan guru, semakin banyak murid yang memajukan pertanyaan dan semakin banyaknya murid yang mampu memecahkan masalah, semakin berkurangnya murid yang meminta bimbingan dan meminta dijelaskan tentang suatu konsep serta semakin berkurangnya murid yang memperhatikan hal-hal diluar jam pelajaran.
\end{abstract}

Kata kunci: keterampilan berpidato, media flash player

\section{Pendahuluan}

Pembelajaran bahasa ialah usaha bagi menuntun perkembangan bahasa ke arah perkembangan bahasa yang diinginkan yang dilakukan dengan pembuatan kamus, tata ejaan yang normatif, penyusunan tata bahasa yang bagi menjadi acuan bagi pemakai bahasa. Hubungan antara pembangunan nasional dan kesemestaan bahasa dirumuskan hipotesis yang dapat dipertimbanggkan oleh pembuat garis kebijbagi perencanaan bahasa Indonesia yang merujuk kepada masa kini dan masa depan.

Secara umum variasi suatu bahasa dapat dilihat dalam 3 dimensi yakni dimensi regional, dimensi sosial, dan dimensi temporal. Bagi meneliti variasi sosial bahasa Indonesia dewasa ini sangatlah mudah karena keheterogenan bangsa Indonesia. Dalam 
taraf pertumbuhan bahasa Indonesia yang homogen masih sangat sulit karena hampir setiap lapisan masyarakat Indonesia dipengaruhi oleh bahasa daerah atau variasi regional tertentu. Kita memakai bahasa secara betul jika kita mempergunbagi bahasa standar sesuai dengan fungsinya. Harimurti Kridalaksana mengatbagi bahwa kodifikasi ialah tindbagi lebih lanjut sesudah terjadi standardisasi. Dalam pekembangan selanjutnya kodifikasi bahasa malahan mempercepat pembakuan bahasa. Pengertian bahasa baku sebenarnya tidaklah terlalu tepat karena bagaimanapun juga terdapat penyimpangan dalam pemakaiaannya meskipun bahasa baku jauh lebih baik dan mantap dibandingkan dengan bahasa non baku. Diterimanya suatu variasi dialek menjadi variasi baku nyata melalui proses secara berturut-turut mulai dari proses seleksi, kodifikasi, elaborasi fingsi dan keberterimaan.

Bagi memahami wujud variasi baku bahasa Indonesia, maka sebaiknya kita melihat dari dua dimensi yakni bentuk dan nilai sosialnya. Variasi baku bahasa Indonesia banyak dibicarbagi pada bidang otografi, fonologi, morfologi, leksikal dan sintaksis, usaha yang dilakukan oleh pemerintah melalui pusat bahasa telah menghasilkan pembakuan di bidang ejaaan, di bidang tata bahasa dan di bidang kosakata. Ada lima cara yang dapat dipakai dalam pembakuan bahasa yakni otorita, bahasa penulis-penulis terkenal, dmokrasi, logika dan bahasa murid-murid yang dianggap terkemuka oleh masyarakat.

Implikasi lebih lanjut menyangkut pendidikan bahasa Indonesia tidak diragukan lagi bahwa bahasa Indonesia yang diajarkan di sekolah pada umumnya ialah variasi baku. Kemahiran dan kemampuan menggunbagi variasi baku bahasa Indonesia, baik lisan maupun tulisan diharapkan dapat dilakukan oleh murid, pelajar, dan mahamurid. perlu disadarkan tentang adanya variasi-variasi sosial bahasa Indonesia yang lain selain dari bahasa baku dan yang diajarkan di sekolah hanyalah variasi baku maka dngan demikian murid, pelajar dan mahamurid menyadari bahwa bahasa yang baik dan benar ialah variasi baku. Prinsip ini sebaiknya dianut oleh para guru bahasa, walaupun para linguis tidak menyetujui variasi baku sebagai satu-satunya bahasa yang baik, betul daan benar.

Berdasarkan hasil observasi dengan guru bahasa Indonesia di SMA Negeri 1 Sinjai Tengah Kabupaten Sinjai pada tanggal 3 Maret 2019, masih banyak murid yang belum mencapai ketuntasan belajar minimal yakni, rata-rata dari murid baru mencapai ketuntasan 70. Selain masih rendahnya ketuntasan belajar, hal ini terlihat dari kurangnya persiapan dan minat murid ketika waktu pelajaran Bahasa Indonesia dimulai di kelas. Meskipun setiap murid sudah mempunyai sumber belajar (buku paket Bahasa Indonesia), bagi tetapi mereka masih saja ada yang lupa membawanya ataupun mereka membawanya tapi hanya dibawa saja, tidak mencoba bagi memahaminya. Selain itu, cara mengajar guru masih cenderung monoton menggunbagi metode ceramah sehingga dapat mengurangi minat belajar murid. Oleh karena itu, peneliti berinisiatif mengguanbagi media pembelajaran agar murid lebih termotivasi dalam proses pembelajaran. Khususnya dalam pembejaran berpidato. Media yang digunbagi yakni media flash player gaya bahasa.

Pembelajaran bahasa di Indonesia sasaran utamanya ialah pembakuan bahasa. Oleh karena bangsa Indonesia ialah multibahasawan, maka baik bahasa Indonesia maupun bahasa daerah hendaknya ditangani secara cermat dan bijaksana karena pada hakikatnya bahasa-bahasa yana bahasng ada di Nusantara ialah warisan kebudayaan yang harus tetap dipelihara. Menyuburkan dan mengembangkan bahasa nasional, yakni bahasa Indonesia bukanlah seharusnya membunuh bahasa daerah karena bahasa 
daerah maupun bahasa Indonesia mempunyai fungsi masing-masing dalam masyarakat pemakainya dan kedua bahasa tersebut dijamin dalam Undang-Undang Dasar 1945 dan penjelasannya.

Adapun rumusan masalah dalam penelitian ini ialah, Bagaimanakah penggunaan media flash player dalam meningkatkan keterampilan berpidato murid kelas X SMA Negeri 1 Sinjai Tengah Kabupaten Sinjai? Dengan tujuan bagi mendeskripsikan penggunaan media flash player dalam meningkatkan keterampilan berpidato murid kelas X SMA Negeri 1 Sinjai Tengah Kabupaten Sinjai.

Berbicara ialah ketarampilan dalam menyampaikan pesan yang dilakukan secara lisan. Berbicara ialah bercakap, berbahasa, mengutarbagi isi pikiran dengan perkataan baik secara lisan maupun tulisan (KBBI, 1996: 144). Maidar dan Mukti (1988: 17) mengatbagi bahwa kemampuan berbicara ialah kemampuan mengucapkan bunyi-bunyi artikulasi atau kata-kata bagi mengekspresikan, menyatbagi, menyampaikan pikiran, gagasan, dan perasaan.

Salah satu keterampilan pembicara ialah keterampilan mengucapkan bunyibunyi artikulasi atas kata-kata bagi mengekspresikan, menyatbagi serta menyampaikan pikiran, gagasan, dan perasaan. Sebagai bentuk atau wujudnya berbicara disebut sebagai suatu alat bagi mengomunikasikan gagasan-gagasan yang disusun serta dikembangkan sesuatu dengan kebutuhan-kebutuhan sang pendengar atau penyimak (Tarigan, 1979: 16). Sedangkan menurut Munirah (2010: 49) mengatbagi bahwa keterampilan berbicara ialah keterampilan memproduksi arus system bunyi artikulasi bagi menyampaikan kehendak, kebutuhan perasaan dan keinginan kepada murid lain.

Pidatoialahsuatuucapandengansusunan yang baikbagidisampaikankepada murid banyak. Pidatojugaberartikegiatansesemurid yang dilakukan di hadapan murid banyakdenganmengandalkankemampuanbahasasebagaialatnya.Pidato yakni suatu ucapan dengan susunan yang baik bagi disampaikan kepada khalayak ramai.contoh : pidato kenegaraan, pidato kegamaan, pidato sambutan dll.

Adobe Flash player ialah sebuah program yang didesain khusus oleh Adobe dan program aplikasi standar authoring tool professional yang digunbagi bagi membuat animasi dan bitmap yang sangat menarik bagi keperluan pembangunan situs web yang interaktif dan dinamis. Flash didesain dengan kemampuan bagi membuat animasi 2 dimensi yang handal dan ringan sehingga flash banyak digunbagi bagi membangun dan menyerahkan efek animasi pada website, CD Interaktif dan yang lainnya. Selain itu, juga dapat digunbagi bagi membuat animasi logo, movie, game, pembuatan navigasi pada situs web, tombol animasi, banner, menu interaktif, interaktif form isian, e-card,screen saver dan pembuatan aplikasi-aplikasi web lainnya.

\section{Metode Penelitian Jenis Penelitian}

Penelitian ini ialah jenis penelitian tindbagikelas (Classroom Action Research) yang berguna bagi meningkatkan kemampuan murid dalam keterampilan berpidato dengan menggunbagi media flash player. Penelitian ini dilaksanbagi dalam bentuk kegiatan bersiklus yang terdiri dari empat tahap yakni perencanaan, pelaksanaan tindbagi, observasi dan refleksi. 


\section{Lokasi dan Pokok Penelitian}

Lokasi penelitian bertempat di SMA Negeri 1 Sinjai Tengah Kabupaten Sinjai.Pokok dalam penelitian ini ialah murid kelas X SMA Negeri 1 Sinjai Tengah sebanyak 33 murid, yang terdiri atas 15 murid laki-laki dan 18 murid perempuan.

\section{Fokus Penelitian}

Fokus penelitian yang dimaksudkan dalam penelitian ini ialah hal atau unsur yang diteliti berdasarkan tujuan penelitian. Adapun fokus penelitian dalam penelitian ini ialah penggunaan media flash player bagi meningkatkan keterampilan berpidato murid kelas X SMA Negeri 1 Sinjai Tengah Kabupaten Sinjai.

\section{Prosedur Penelitian}

Penelitian ini dilaksanbagi dalam dua siklus, yakni Siklus I dan Siklus II. Setiap siklus bagi diberikan tes hasil belajar bagi mengetahui keterampilan berpidato yang dicapai murid. Dengan perumusan sebagai berikut: Siklus I dilaksanbagi sebanyak 4 kali pertemuan dan siklus II dilaksanbagi sebanyak 4 kali pertemuan. Dalam artian bahwa pelaksanaan siklus II ialah kelanjutan dan perbaikan dari siklus I, dengan langkahlangkah yakni perencanaan, pelaksanaan, pengamatan, dan refleksi.

\section{Instrumen Penelitian}

Bagi menjaring data yang diperlukan dalam kegiatan penelitian ini, peneliti memilih dan merancang beberapa instrumen yang relevan dengan tujuan penelitian. Instrumen dalam penelitian ini yakni: (1) lembar observasi aktivitas murid dan tes hasil belajar.

\section{Teknik Pengumpulan Data}

Sesuai dengan rencana penelitian, maka data dalam penelitian ini bagi dikumpulkan dengan cara sebagai berikut, data hasil belajar murid dikumpulkan melalui pemberian tes berpidato kepada murid pada setiap siklus dan lembar observasi diberikan kepada semurid pengamat bagi diisi dengan cara menuliskan cek list $(\sqrt{ })$ sesuai dengan keadaan yang diamati.

\section{Teknik Analisis Data}

Data yang telah dikumpulkan bagi dianalisis secara kualitatif dan kuantitatif. Hasil observasi dianalisis secara kualitatif. Sedangkan data mengenai hasil belajar bagi dianalisis secara kuantitatif dan menggunbagi statistik deskriptif.Bagi mengukur secara kuantitatif hasil belajar bahasa Indonesia murid bagi digunbagi teknik pengkategorian dengan skala lima berdasarkan teknik standar yang diterapkan.

\section{Indikator Keberhasilan}

Adapun indikator keberhasilan aktivitas belajar murid terhadap kemampuan berpidato bersumber dari hasil belajar murid dengan menggunbagi media flash player dengan kriteria ketuntasan belajar yang digunbagi sekolah SMA Negeri 1 Sinjai Tengah yakni 65, maka bagi mengetahui keberhasilan tersebut digunbagi nilai ketercapaian yakni 65.

\section{Hasil Penelitian}

Hasil analisis kuantitatif tes kemampuan berpidato murid kelas X SMA Negeri 1 Sinjai Tengah Kabupaten Sinjai pada siklus Idengan menggunbagi media flash player, maka secara statistik deskriptif yakni dari 33 murid kelas X SMA Negeri 1 Sinjai Tengah, skor rata-rata nilai murid yang diperoleh ialah 59,66dengan nilai tertinggi 80 dan nilai terendah 42 serta standar deviasi 11,32. Jika keseluruhan nilai yang diperoleh murid dikonversikan dalam skala lima, maka selengkapnya seperti tabel 4.2 berikut ini: 
Tabel 4.2 Analisis Data Berdasarkan Skala Lima Siklus I

\begin{tabular}{|c|c|c|c|}
\hline Interval & Kategori & $\begin{array}{c}\text { Jumlah } \\
\text { (frekuensi) }\end{array}$ & $\begin{array}{c}\text { Persentase } \\
\mathbf{( \% ) ~}\end{array}$ \\
\hline $0-34$ & Sangat Rendah & - & - \\
\hline $35-54$ & Rendah & 10 & 30,30 \\
\hline $55-64$ & Sedang & 12 & 36,36 \\
\hline $65-84$ & Tinggi & 11 & 33,33 \\
\hline $85-100$ & Sangat Tinggi & & - \\
\hline & Jumlah & 33 & 100 \\
\hline
\end{tabular}

Berdasarkan tabeldi atas memperlihatkan bahwa nilai yang diperoleh murid kelas X SMA Negeri 1 Sinjai Tengah setelahpengunaan media flash playerdapat dikategorikan tidak ada murid (0\%) yang masuk kategori sangat rendah dan 10 murid atau $30,30 \%$ berada pada kategori rendah. Kemudian, murid masuk dalam kategori sedang, yakni 12 murid dengan persentase 36,36\% dan murid yang berada pada kategori tinggi yakni 11 murid dengan persentase 33,33\%, serta tidak ada murid masuk kategori sangat tinggi (0\%).

Apabila skor ketuntasan murid dikelompokkan kedalam dua kategori, maka diperoleh distribusi frekuensi skor ketuntasan yang ditunjukkan pada tabel 4.3 berikut:

Tabel 4.3Distribusi Frekuensi Ketuntasan Skor Hasil Belajar Bahasa Indonesia Kelas X SMA Negeri 1 Sinjai Tengah

\begin{tabular}{|c|c|c|c|}
\hline Skor & Kategori & Frekuennsi & $\begin{array}{c}\text { Persentase } \\
\text { (\%) }\end{array}$ \\
\hline $0-64$ & Tidak Tuntas & 22 & 66,66 \\
\hline $65-100$ & Tuntas & 11 & 33,33 \\
\hline \multicolumn{2}{|r|}{ Jumlah } & 33 & 100 \\
\hline
\end{tabular}

b. Analisis data kualitatif siklus I

1) Observasi Partisipasi Murid

Pengamatan aktiviitas murid (observasi) menunjukan bahwa pada siklus I, dari 33 murid kelas X. Murid yang hadir pada saat kegiatan pembelajaran sebanyak 87,87\%, murid yang menjawab pertanyaan lisan guru pada saat penjelasan materi17,15\%, Murid yang memperhatikan materi pembelajaran yang sedang berlangsung 48,48\%, murid yang bertanya saat prosesp pembelajaran $16,15 \%$, danmurid yang melakukan kegiatan lain (ribut, bermain, dll) 19,18\%. Dar hasil observasi mengenai aktifitas murid pada siklus I dinyatbagi murid masi kurang antusias dalam mengikuti pelajaran.

c. Refleksi Siklus I

Siklus I dilaksanbagi 4 kali pertemuan dalam pembelajaran. Pada siklus I tampak masih banyak murid yang tidak hadir mengikuti pelajaran baik itu tidak hadir tanpa keterangan maupun yang sakit. Hal ini disebabkan karena murid menganggap bahwa pelajaran bahasa Indonesia dalam keterampilan berpidato itusulit dan rumit bagi dilakukan dan mengangap pelajaran berbicara bahasa Indonesia ialah pelajaran yang tidak terlalu penting. 
Hasil yang didapat pada siklus I belum menujukkan hasil yang optimal dan media yang digunbagi belum terserap dengan baik pada murid maka perlu dilanjutkan pada siklus II.

\section{Analisis Data Siklus II}

\section{a. Analisis Kuantitatif Tes Hasil Belajar Siklus II}

Setelah melalui beberapa kali revisi pada siklus I, maka tes hasil belajar bahasa Indonesia dalam keterampilan berpidato dengan media flash playermurid kelas X SMA Negeri 1 Sinjai Tengah pada siklus II memperlihatkan bahwa telah terjadi peningkatan tes hasil belajar yang diperoleh murid dalam keterampilan berpidato, dengan nilai ratarata ialah 72,24.Nilai tertinggi yang diperoleh murid yakni90 dan nilai terendah 50 serta standar deviasi 12,20.

Apabila keseluruhan nilai tersebut dikonversikan ke dalam skala lima, maka selengkapnya seperti tersaji pada tabel 4.5 berikut ini:

Tabel 4.6 Analisis Data Berdasarkan Skala Lima Siklus II
\begin{tabular}{|c|c|c|c|}
\hline Interval & Kategori & $\begin{array}{c}\text { Jumlah } \\
\text { (frekuensi) }\end{array}$ & $\begin{array}{c}\text { Persentase } \\
\mathbf{( \% )}\end{array}$ \\
\hline $0-34$ & Sangat Rendah & - & - \\
\hline $35-54$ & Rendah & - & - \\
\hline $55-64$ & Sedang & 9 & 27,27 \\
\hline $65-84$ & Tinggi & 15 & 45,45 \\
\hline $85-100$ & Sangat Tinggi & 9 & 27,27 \\
\hline & Jumlah & $\mathbf{3 3}$ & $\mathbf{1 0 0}$ \\
\hline
\end{tabular}

Berdasarkan tabel 4.6 di atas memperlihatkan bahwa tidak ada murid yang masuk kategori sangat rendah dan rendah (0\%). Murid yang masuk kategori sedang mengalami penurunan dimana pada siklus I sebanyak 12 murid. Namun, pada siklus II hanya 9murid atau 22,27\%, sedangkan murid yang masuk kategori tinggi mengalami peningkatan dari 11 murid pada siklus I menjadi 15murid atau 45,45\% pada siklus II. Kemudian, murid yang berada pada kategori sangat tinggi yakni 9 murid atau 27,27\%.

Apabila skor ketuntasan murid dikelompokkan kedalam dua kategori, maka diperoleh distribusi frekuensi skor ketuntasan yang ditunjukkan pada tabel 4.6 berikut:

Tabel 4.7 Distribusi Frekuensi Ketuntasan Skor Hasil Belajar Bahasa Indonesia Kelas X SMA Negeri 1 Sinjai Tengah

\begin{tabular}{|c|c|c|c|}
\hline Skor & Kategori & Frekuennsi & $\begin{array}{c}\text { Persentase } \\
\text { (\%) }\end{array}$ \\
\hline $0-64$ & Tidak Tuntas & 9 & 27.27 \\
\hline $65-100$ & Tuntas & 24 & 72,72 \\
\hline \multicolumn{2}{|r|}{ Jumlah } & $\mathbf{3 3}$ & $\mathbf{1 0 0}$ \\
\hline
\end{tabular}




\section{b. Analisis data kualitatif siklus II}

1) Observasi Partisipasi Murid

Hasil observasi sebagai data tentang keaktifan murid. Hasil observasi aktivitas pembelajaranpada siklus IImenunjukan aktivitas murid sudah terlihat dengan jelas adanya keseriusan dan keantusiasan murid dalam mengikuti pelajaran. Hal ini terlihat pada beberapa indikator mengalami peningkatan frekuensi di mana hampir semua murid ikut terlibat di dalamnya, ini disebabkan karena minat belajar murid. Indikator yang perlu ditekankan, yakni murid yang hadir pada saat kegiatan pembelajaran meningkat sebanyak $95,93 \%$, murid yang menjawab pertanyaan lisan guru pada saat penjelasan materi yakni28,27\%, Murid yang memperhatikan materi pembelajaran yang sedang berlangsung yakni59,57\%, murid yang bertanya saat prosesp pembelajaran meningkat sebanyak37,36\%, danmurid yang melakukan kegiatan lain (ribut, bermain, dll) mengalami penurunan menjadi13,12\%. Dari hasil observasi mengenai aktifitas murid pada siklus IIdinyatbagi murid lebih antusias dalam mengikuti pelajaran. Hal ini menunjukan bahwa peningkatan antusias murid dalam belajar sangat signifikan.

c. Refleksi Siklus II

Berdasarkan hasil observasi yang menjadi rekaman pelaksanaan tindbagi pada siklus II dapat dipaparkan perubahan-perubahan sikap yang terjadi dalam realisasi tindbagi terhadap proses aktivitas belajar dikelas dalam kegiatan berlangsung. Sikap murid sudah menunjukan antusias dalam mengikuti pelajaran bahkan sebagian murid senang dengan media yang digunbagi guru karena dapat menambah pemahaman murid dalam keterampilan berpidato apa lagi didukung oleh lingkungan belajar yang menarik.

Kemampuan murid dalam berpidato semakin meningkatsetelah penggunaan media flah player. Hal ini dapat dilihat dari hasil belajar murid yang semakin meningkat. Dengan demikian, dapat diktbagi bahwa kualitas belajar mengajar pada siklus II ini semakin baik.

\section{Pembahasan}

Dari hasil analisis kuantitatif dan kualitatif tampak bahwa pada dasarnya penggunaan media flash palyerjika digunbagi dalam keterampilan berpidato murid kelas X SMA Negeri 1 Sinjai Tengah, dapat menyerahkan perubahan nilai dan perilaku murid dalam proses pembelajaran. Hal ini dinyatbagi karena sebelum penggunaan media flash player, yang diterapkan guru ialah pengajaran yang berpusat keaktifan guru dan ketika murid diberi suatu masalah, mereka tidak mampu memecahkan masalah tersebut dengan usaha sendiri.

Berbeda dengan penggunaan media flash playerdalam peningkatan hasil belajar keterampilan berpidato murid kelas X SMA Negeri 1 Sinjai Tengah kabupaten Sinjai, yang sangat menekankan pada kecekatan murid dalam membawbagi sebuah pidato. Murid diharapkan memperlihatkan sejauh mana penguasaan materi pidato yang bagi dibawbagi.

Pada tes akhir siklus I nilai rata-rata murid ialah 59,66 sedangkan pada hasil tes siklus II nilai rata-rata muridyakni 72,24 . Hal ini memperlihatkan bahwa terjadi peningkatan terhadap hasil belajar murid dari siklus I ke siklus II.

Persentase ketuntasan hasil belajar murid dalam keterampilan berpidato pada siklus Imurid yang mendapat nilai 0-64 sebanyak 22 murid denga persentase $(66,66 \%)$ dan murid yang mendapa nilai 65-100 sebanyak 11 murid dengan persentase (33,33\%). Sedangkan pada siklus II murid yang mendapat nilai 0-64 sebanyak 9 murid denga persentase $(27,27 \%)$ dan murid yang mendapa nilai $65-100$ sebanyak 24 murid dengan 
persentase $72,72 \%$ ). Jadi, dapat dinyatbagi bahwa penggunaan media flash player dapat meningkatkan keterampilan berpidato murid.

Dari uraian diatas dapat disimpulkan pada siklus II pelaksanaan proses pembelajaran dengan menggunbagi model media flash player berjalan lebih baik dibandingkan dengan siklus sebelumnya, ini memperlihatkan bahwa perubahan sikap murid dari siklus I ke siklus II selalu mengarah pada hal-hal yang telah direncanbagi sesuai dengan langkah-langkah yang telah disiapkan pada prosedur penelitian. Jadi, dapat dinyatbagi bahwa hipotesis yang diajukan diterima karena terjadi peningkatan hasil belajar dengan menggunbagi media flash player pada murid kelas X SMA Negeri 1 Sinjai Tengah Kabupaten Sinjai.

\section{Simpulan}

Berdasarkan hasil belajar bahasa Indonesia dalam keterampulan berpidato dengan menggunbagi media flash player bahwa pada siklus I hasil belajar murid dikategorikan sedang dengan nilai rata-rata pada siklus I sebesar 33,33\% atau 11 murid dari 33 murid berada dalam kategori tuntas dan 66,66\% atau 22 murid dari 33 murid berada dalam kategori tidak tuntas. Hal ini berarti bahwa terdapat 22 murid dari 33 murid yang perlu perbaikan karena belum mencapai kriteria ketuntasan individual. Kemudian, meningkat pada siklus II $72,72 \%$ atau 24 dari 33 murid berada dalam kategori tuntas dan 27,27\% atau 9 dari 33 murid berada pada kategori tidak tuntas.

Dengan demikian, penggunaan media flash player dalam meningkatkan keterampilan berpidato murid kelas X SMA Negeri 1 Sinjai Tengah mengalami peningkatan.

\section{Saran}

Berdasarkan hasil yang diperoleh dalam penelitian ini agar tercapai hasil yang optimal, maka beberapa hal yang disarankan sebagai berikut:

1) Pengunaan media flash player dapat diaplikasikan dalam pembelajaran dalam meningkatkan hasil belajar bahasa Indonesia keterampilan berpidato.

2) Disarankan kepada guru terutama mata pelajaran bahasa Indonesia bahwa dalam memilih metode/media pembelajaran harus disesuaikan dengan mata pelajaran dan kondisi murid di kelas dan salah satu media pembelajaran yang cocok dalam meningkatkan hasi belajar berpidato ialah penggunaan media flash player 


\section{Daftar Pustaka}

Adidharmodjo, Gunawan Wibisono. 1989. Renda-Renda Bahasa. Bandung: Perceratbagi Offset Angkasa.

Arikunto, Suharsimi. 2006. Prosedur Penelitian Suatu Pendekatan Praktik. Jakarta: Rhineka Cipta.

Danim, Sudarwan. 1997. Metode Penelitian bagi ilmu-ilmu prilaku. Jakarta: Bumi Aksara. Djago, Tarigan, dkk. 1997. Pengembangan Keterampilan Berbicara. Jakarta: Depdikbud.

Emzier. 2008. Metodologi Penelitian Kualitatif dan Kuantitatif. Jakarta: PT Rajagrafindo Persada.

Hastuti, Sri, dkk. 1985. Kemampuan Berbahasa Indonesia Murid Sekolah Dasar VI Kotamadya Surabaya. Jakarta: Depdiknas.

Keraf, Gorys. 1994. Diksi dan Gaya Bahasa. Jakarta: PT Gramedia Pustaka Utama

Maidar, Arsjad, G. dan Mukti. 1991. Pembinaan Kemampuan Berbicara Bahasa Indonesia. Jakarta: Erlangga.

Munirah. 2010. Model dan Strategi pembelajaran Bahasa Indonesia. Makassar: Unismuh Makassar.

Nurgiyantoro, Burhan. 2005. Penilaian dalam Pengajaran Bahasa dan Sastra. Yogyakarta: BPFE.

Sugiyono. 2012. Statistika bagi Penelitian. Bandung: Alfabeta.

Tarigan, Henry Guntur. 1979. Berbicara Sebagai Suatu Keterampilan Berbahasa. Bandung: Angkasa 